\title{
Trust as a Factor of Political Mobilization of Society in the Conditions of Establishment of Democracy
}

\author{
Nataliia Iskhakova \\ Ph.D. in Political Sciences, Associate Professor, National Aviation University \\ (Kyiv, Ukraine) \\ E-mail: iskhakova@edu.ua \\ https://orcid.org/0000-0002-6356-1580
}

The process of political mobilization of population as finishing stage of democratization of society is studied. Citizens' trust for democratic institutions is defined as a basic factor of political mobilization of the population. Ukraine has not implemented the task of co-operation of citizens in voluntary associations. The reason for this is the low level of trust in democratic institutions.

Keywords: political trust; political mobilization; political activity; political participation; democratization

Received: November 21, 2018; accepted: December 2, 2018

Ukrainian Policymaker, Volume 3, 2018: 11-16.

https://doi.org/10.29202/up/3/2

\section{Introduction}

Recently, a dangerous tendency to increase spontaneous protests of the population with a low ability to organized forms of participation in the political process is emerging in Ukraine. This trend can be traced throughout the newest Ukrainian history, especially in the events of 2004 and 2013-2014. Due to the slow formation of the practices of collective political activity, the tasks of activating large sections of the population in politics, of co-operating citizens into voluntary associations remain unfulfilled. Therefore, the problem of trust as a basic factor of political mobilization of citizens is actual. This is especially important in the context of the constantly low level of trust of the population of Ukraine to all state bodies and democratic institutions over the past two decades.

\section{Analysis of recent research and publications}

The interest of researchers to the problems of political mobilization is connected with the work of Karl Deutsh "Social Mobilization and Political Development", in which he described

(C) Iskhakova, Nataliia, 2018 
the role of mobilization in the conditions of democratization (modernization) of society. Through mobilization, citizens are able to fulfill new political roles and assimilate new models of political socialization [Deutsch, 1964]. In the context of the modern theory of democracy, a view was developed on political mobilization as participation in the political process of autonomous rational individuals (J. Schumpeter). Russian researcher Dmitry Goncharov in the framework of the theory of political participation analyzed mobilization models of voters [Goncharov, 1995: 129].

Recently, in the domestic scientific literature, political mobilization has been increasingly considered by researchers in the field of mass communication. Therefore, on the strengthening of the population using Internet resources to participate in protest actions drew the attention Julia Ilyicheva [Ilyicheva, 2013: 129]. Ukrainian researcher Tatyana Kremin [Kremen, 2013: 146]. Proved that social media are an effective means of political mobilization, in particular in stable Western countries. In the dissertation research, Alla Mischenko established that the confidence of the majority of citizens in political institutions is a basic factor in democratic reforms [Mishchenko, 2010].

\section{Allocation of previously unsolved parts of the general problem}

In modern Ukrainian science, the problem of trust as a basis for social and political mobilization has not been studied. This is despite the fact that there is a serious need to increase the level of collective political participation in the context of democratization. In the modern Ukrainian society, the tasks of activating the population in politics and cooperating citizens in voluntary associations remain unfulfilled.

Purpose of the article. The main purpose of this article is to present the process of political mobilization of the masses as the final stage of democratization of society and define political trust as the basic factor of mobilization of the population to participate in the political life.

\section{The presentation of the main material}

Political mobilization of the population is an integral part of the process of democratic transformation of modern society. The theorists of "transitology" note the importance of political mobilization of the masses, without which system changes are impossible.

In this regard, we can mention the dynamic model of the transition to democracy by the American political scientist Dankwart Rustow [Rustow, 1996: 5]. The scientist highlighted the main phases of democratization, emphasizing the role of the subjective factors of a such transition. These phases are considered by modern political scientists as those that are characteristic of all transitional societies. The scientist assigned a special role to the final phase ("addiction"), where the political activization of the population takes place, contributes to the adoption of a new form of interaction between civil society and the state. In this way, democratic political institutions and procedures are consolidated. Mobilization of broad strata is important not only at the final stage of democratization, but at the beginning of this process. This model also provided for the existence of the main prerequisite for the transition to democracy - national unity, the awareness of the majority of citizens of belonging to a single political community.

In a thorough study "Transitions from Authoritarian Rule: Tentative Conclusions about Uncertain Democracies" (1986). The authors G. O'Donnell and F. Schmitter carried out a comparative analysis of the transition processes in the countries of Southern Europe and Latin 
America. The authors concluded that the political mobilization of the population is the final stage of the transition to democracy. This is the "re-socialization" stage, that is, the assimilation by citizens of new political norms and values from gradually entering into a new system of political relations [Kharitonova, 1996: 70].

One of the most thoughtful and logical, regarding the explanation of the democratic transformation of societies, is the theory of the sequence of the individual phases of the Zbigniew Brzezinski phase [Brzezinski, 2006: 204]. According to the scientist, only in the last phase is political stability achieved as a result of the consolidation of a democratic political and legal culture.

Under the social-political mobilization should be understood the process of activization of individuals and social groups in politics on a permanent basis. This is an associative (collective) political activity, which implies a high level of participation of the masses in politics. Political mobilization is the process of attracting individuals and groups to various forms of political activity (political parties, social movements, etc.).

In practice, democratic transformations first liberalize the regime, which expands the possibilities of political activity of individuals and social groups. That is, the activation of non-state institutions (associations, organizations, citizen associations, etc.) begins, which contributes to the wide participation of citizens in the political process. It is important to emphasize the need for the organizational side of such participation, as opposed to spontaneous mass protests. Therefore, gradually civil activity becomes the norm of the political behavior of the population. Consolidation of democracy is the final stage of democratic transformation. At this stage, there is an "addiction" or adaptation of the population to new political mechanisms and the legitimation of a new democratic regime. According to Dmitrii Fadeev, "consolidation of the regime is the process of establishing and adapting democratic structures, institutions and norms that are partially or fully recognized by civil society as legitimate" [Fadeev, 1992: 117].

Thus, the success of democratization processes directly depends on the adaptation of citizens to the new political system. The establishment of a new relationship between a person and political power depends on the quality of collective actions in politics (organized political participation) of different groups and individuals. Mobilization of the masses in the political process by non-state institutions is an indicator of the quality of democratic changes. While the political activity of the broad strata does not acquire signs of autonomy, organization and constancy, it is too early to talk about significant changes in the political system. Therefore, the level of civil activity can be an indicator of the democratization of the political regime.

Important consequences of such self-organization of citizens should be the emergence of new collective actions for protections their interests and desire. At the same time, collective actions in politics should not be chaotic, but within the framework of social or legal norms.

Such a scenario, of democratic transformations with the key role of political mobilization of the masses has already passed the countries of the so-called "preliminary wave" of the last century. Examples include Spain (in the 1970s), where the persecution of labor movements was weakened at the liberalization stage, and Brazil (the 1980s), where social organizations immediately became active. Thus, the reduction of state controlled to the political activization of citizens.

Increasing the level of political mobilization of the masses has a number of consequences in the socio-political sphere:

a) Stabilization of the system of needs and social expectations;

b) Learning the new system of roles and norms of behavior;

c) Non-state regulation of political activity of the population; 
d) Awareness of goals in the political sphere through the development of group selfawareness.

This contributes to the adoption of a model of socially-organized democracy (A. Przeworski).

However, the provisions and examples of the theory of democratization cannot be fully applied to the transformation processes of post-Soviet countries, including Ukraine. The political activity of the citizens of these countries is complicated by paternalistic expectations, which are rooted in the mass consciousness. In addition, distrust of the institutions of power causes disinterest and indifference to political life. In these countries, loyalty to democracy directly depends on the success of economic transformations.

Therefore, at the present stage of democratic transformations, the importance of the main subjects of mobilization increases. According to the Ukrainian scientist Tatyana Kremen, the main subjects are associations, i.e. formal associations having an organizational structure and management apparatus; political, spiritual leaders, moral authority.

Add to the above, the fact that political trust acts as the main basis of democratic transformations. It is included in the process of forming heterogeneous forms of public associations. Without this, it is impossible to achieve a consolidation of society on the basis of a minimum consensus. Trust is one of the main factors of the political mobilization of the masses in a democracy and ensures the smooth functioning of its institutions. Democracy needs a foundation of social trust, and a decline in the level of institutional support from civil society will inevitably lead to fundamental changes in the political system.

According to the scientist Galina Zabolotnaya, the social base of support of the institutions of power and their political and economic course provides confidence, which is directly connected with the mechanism of legitimizing authority [Zabolotnaya, 2003: 67]. This statement emphasizes the importance of political trust of citizens during the period of unification for the effective and stable functioning of these structures. In addition, in the late 1950 s - early 1960s, in the work of G. Almond and S. Verba "Civic Culture" it was proved that only the trust of the majority of citizens to the existing state of affairs is the basis of civil culture, that is, democratization of society.

Here we should pay attention to the fact that even in stable democracies sociological researches state a massive distrust of citizens towards government bodies. However, in this case there is a number of legal procedures, for example, the people's dissolution of government, the people's constitutional and legislative initiative, the people's assembly of citizens, and the recall of a deputy by voters. In addition, there is a mechanism of expression of no confidence in the government by the government.

The above- mentioned only confirms the interrelation of phenomena: political trust consolidation of citizens - civil activity. The higher the level of associative everyday political participation of citizens, the higher is the indicator of citizens' political confidence in the political regime as a whole. As an example, we can recall the transformation processes of Eastern Europe (in particular, Poland and Hungary) in the early 1990s of the 20th century. There, trust in democratic institutions and procedures helped to increase the activity of non-governmental organizations and, ultimately, establish a democratic political regime. Therefore, when sociologists began to record a decline in the level of political mobilization of the population in American society, alarming publications immediately appeared about the threat to the existence of a democratic system. Therefore, S. Lipset and W. Schneiderstated that people began to express themselves more and more critical about the actions (results) of the main institutions [Dogan, 1999: 85]. 
Therefore, for countries that are only striving to establish democracy, a huge problem is to strengthen the confidence of citizens as the basis for their political mobilization. Unfortunately, trust in political leaders is often identified with democratic institutions, which leads to a decrease in trust in parties, government, parliament, head of the state, state administrations, the media, etc.

Ukrainian researcher Alla Mischenko highlighted factors that prevent the modern Ukrainian authorities from gaining a sufficient level of trust: the inefficiency of the political elite, administrative pressure, the manipulation of spiritual values. All this may constitute the risk of a return to an authoritarian political regime [Mischenko, 2010].

\section{Conclusions}

The process of political mobilization of large sections of the population is the final stage of the democratization of society and an indicator of the quality of systemic transformations. In modern Ukrainian society, the tasks of activating the population in politics and of co-operating citizens into voluntary associations remain unfulfilled. In the future, Internet resources are an effective means of mobilizing the Ukrainian population for political participation. The Internet has enormous potential to influence people's minds and feelings, their way of thinking and political motivation. The introduction of a civil education system minimizes manipulative influences from the media. Acquiring the skills of systemic political activity, especially among young people, can be achieved by consolidating the efforts of various mobilization actors.

In further studies of the quality of democratic reforms in Ukraine, the scale of the political mobilization of the Ukrainian population should be taken into account. It will be relevant to analyze the level of political activity of wide sections of the population, the ability of citizens to cooperate in voluntary political associations.

\section{[L] References}

Brzezinski, Zbigniew. Choice: world domination or world leadership. Kyiv: Kyiv-Mohyla Academy, 2006

Deutsch, Karl. Social mobilization and political development. Comparative Politics. Toronto, McClelland and Stewart, 1964.

Dogan, Mattei. Confidence erosion in developed democracies. World economy and international relations, No. 5, 1999: 85-93.

Fadeev, Dmitrii. From authoritarianism to democracy: the laws of the transition period. Polis. No.1-2, 1992: 117-123.

Goncharov, Dmitry. Political mobilization. Polis, No. 6, 1995: 129-137.

Ilyicheva, Julia. Mobilization technologies: essence, background of occurrence, basic tools and means. The theory of mass media and mass communication, No. 2, 2013: 129-137.

Iskhakova, Nataliia. The stages of political adaptation of the population in the process of democratization. Gilea. No. 130 (3), 2018: 366-370.

Iskhakova, Nataliia. Political mobilization of the population: factors and means. Political Science Herald. No. 75, 2014: 287-293.

Kharitonova, Oxana. The genesis of democracy (An Attempt of reconstruct logic of transitological models). Polis. No.5, 1996: 70-78.

Kremen, Tatyana. Political mobilization: objects and subjects. Historical and socio-educational thought, No. 5 (21), 2013: 146-149. 
Mishchenko, Alla. Influence of trust on the legitimation of power in modern Ukraine. Gilea. No 30, 2010: 440-447

Rustow, Dankwart.Transitions to democracy: an attempt at a dynamic model. Polis. No5, 1996: 5-15

Zabolotnaya, Galina.The phenomenon of confidence and its social functions. Vestnik RUDN, Series Sociologia. No. 1 (4), 2013: 67-73. 